\title{
Kajian Hubungan antara Desain Kendaraan MPV dan Penggunanya di Kota Bandung
}

\author{
Slamet Riyadi, Yannes Martinus Pasaribu \& Andar Bagus Sriwarno \\ Program Magister Desain, Fakultas Seni Rupa dan Desain \\ Institut Teknologi Bandung, Jalan Ganesa No. 10 Bandung 40132, Indonesia \\ Email: dhiesign@gmail.com
}

\begin{abstract}
Abstrak. Saat ini kendaraan bermotor sudah menjadi kebutuhan bagi sebagian besar masyarakat kota karena adanya tuntutan mobilitas yang tinggi dengan waktu yang singkat dalam melakukan kegiatan sehari-hari. Kondisi geografis, kekhasan budaya, ekonomi dan gaya hidup pun ikut mempengaruhi perbedaan perilaku masyarakatnya. Indonesia merupakan negara dengan angka penjualan mobil yang tinggi untuk jenis kendaraan multipurpose vehicle (MPV). Meski desain mobil tersebut diluncurkan ke pasar dengan banyak varian, hanya ada satu varian dari masing-masing kendaraan saja yang memiliki tingkat penerimaan pasar yang tinggi di Indonesia, sementara varian lainnya tidak diserap dengan baik oleh pasar. Tujuan dari penelitian ini adalah untuk mengidentifikasi faktorfaktor yang mempengaruhi terjadinya perbedaan antara harapan konsumen dengan konsep desain yang sudah ditawarkan oleh produsen sehingga hanya kendaraan dengan tertentu saja yang diterima oleh konsumen. Penelitian ini dilakukan untuk membuktikan hipotesa bahwa desain mobil yang menggunakan nilai ideal negara produsen dalam beberapa kasus tidak memiliki harapan yang tinggi untuk diterima oleh pasar Indonesia, mengingat adanya perbedaan nilai dan budaya antara negara produsen yakni Jepang dengan masyarakat penggunanya di Indonesia yang mengakibatkan adanya perbedaan persepsi antara konsep desain mobil ideal menurut masyarakat urban di Indonesia dengan konsep yang ditawarkan oleh manufaktur.
\end{abstract}

Kata kunci: desain kendaraan; masyarakat urban; MPV; perilaku; principal; user.

Abstract. Currently motored vehicle has become a necessity for most urban people because the demands of high mobility are performing in their daily activities. Geographical conditions, cultural distinctiveness, economic and lifestyle differences also influence the behavior of its people. Indonesia is a country with a high rate of car sales for multipurpose vehicle (MPV). With this phenomenon, criteria for the Indonesian people about MPV car, with both design aspects and also engineering aspects are no longer controlled by the principal industry in Japan, but should further reflect the desires of consumers in Indonesia. This becomes the basis of the considerations in choosing which vehicle they want to buy. The goal of this research is to identify the factors that influence the occurrence of the difference between consumer choices with a design that has been offered by the manufactures. This study was conducted to prove the hypothesis that car design using ideal values from Japanese country as

Received September $3^{\text {rd }}, 2012$, Revised September $26^{\text {th }}, 2013$, Accepted November $29^{\text {th }}, 2013$

Copyright () 2013 Published by LPPM ITB, ISSN: 1978-3078, DOI: 10.5614/itbj.vad.2013.5.1.4 
the main producer of cars in some cases do not have high hopes of being accepted by the Indonesian market, considering several values and cultural differences between ideal values of Japanese car manufactures and conditions of Indonesian people, which resulted in differences of perceptions, between the ideal concept of car design of urban people in Indonesia and the concept that manufactures has offered.

Keywords: behavior; car design; MPV; principal manufacture; urban people; user.

\section{Pendahuluan}

Mobil menjadi salah satu kebutuhan utama bagi masyarakat kota yang menginginkan kenyamanan dan keamanan pada saat bepergian dalam maupun luar kota. Masyarakat urban Indonesia merupakan salah satu konsumen terbesar penggunaan alat transportasi seperti mobil. Hal ini disebabkan oleh belum adanya industri otomotif buatan dalam negeri yang beredar di Indonesia, dan masyarakat Indonesia sejauh ini hanya sebagai pengguna mobil buatan perusahaan prinsipal yang mendirikan pabrik perakitan dan produksi di Indonesia. Sementara kriteria kebutuhan masyarakat Indonesia akan mobil keluarga, baik dari sisi desain maupun spesifikasi mesin harus semakin merefleksikan keinginan konsumen [1]. Hal ini menjadi dasar pertimbangan masyarakat dalam memilih kendaraan yang akan mereka beli.

Mobil sebagai sarana transportasi masyarakat urban di Indonesia, saat ini telah berkembang menjadi sebuah fenomena. Dinamika perkembangan sosial pada masyarakat urban saat ini menuntut agar sebuah mobil harus memfasilitasi berbagai kriteria dari konsumen pada segmentasi masyarakat urban di Indonesia. Di samping itu, kriteria efisiensi mobil yang sudah harus dipenuhi, seperti: hemat bahan bakar, mudah dalam perawatan, nyaman dalam pengendalian, bertenaga, aman dan ramah lingkungan. Hal ini menjadikan pengembangan desain mobil oleh industri mobil di Indonesia masih mengarah kepada peningkatan efisiensi energi dan biaya tanpa melakukan pendekatan desain yang berpusat pada masyarakat sebagai subyek (inklusif) sehingga masyarakat urban di Indonesia hanya sebagai pengguna mobil dengan desaindesain yang berasal dari prinsipal. Hal ini dianalisis lebih dalam untuk dapat mengetahui faktor-faktor desain yang terdapat dalam kendaraan jenis multipurpose vehicle (MPV) yang menjadi permasalahan masyarakat urban di Indonesia.

\section{$2 \quad$ Kajian Teori}

Kebiasaan merupakan suatu perilaku yang dilakukan secara terus-menerus hingga menjadi sesuatu di mana tidak adanya niat akhirnya menjadi suatu 
bentuk yang menghasilkan kesengajaan dan merupakan proses yang dilakukan secara otomatis. Ketika perilaku akhirnya menjadi suatu kebiasaan, tidak adanya niat akhir menjadi bentuk yang menghasilkan suatu kesengajaan dan merupakan suatu proses yang dilakukan secara otomatis dari pada informasi, Kebiasaan menggunakan kendaraan merupakan hasil dari karakter pengulangan dan tingginya frekuensi penggunaan kendaraan. Hal ini dapat menjelaskan beberapa permasalahan mengapa sangat sulit untuk merubah kebiasaan tersebut. Dalam hal ini, masyarakat Kota Bandung menggunakan kendaraan sebagai suatu bentuk kebiasaan yang dilakukan seperti kendaraan sebagai sarana pendukung pekerjaan, sarana untuk berwisata dan sarana transportasi seharihari.

Seiring dengan daya beli masyarakat urban yang semakin tinggi, tingkat kepekaan masyarakat akan desain sebuah mobil semakin meningkat. Hal ini disebabkan oleh kemampuan manusia dalam mengenali obyek, berasal dari pengalaman dan pengetahuan mereka. Saat otak manusia melakukan proses pengenalan, proses yang secara aktif terjadi adalah proses menginterpretasikan citra visual yang diterima dan membandingkannya dengan medan pengalaman mereka sebelumnya. Jika dikaitkan dengan konteks desain, maka kekuatan brand dan faktor harga dari sebuah produk mobil bukan lagi menjadi faktor penentu utama dalam usaha ATPM meningkatkan angka penjualan mobilnya di masyarakat urban di Indonesia, melainkan ada faktor-faktor penentu lainnya yang mempengaruhi persepsi dan keputusan membeli.

Menurut Kotler [2], dalam menentukan sebuah produk yang akan dibeli, konsumen dipengaruhi oleh beberapa faktor yang membentuk perilaku mereka dalam mengambil keputusan, sebagai berikut:

1. Faktor Kebudayaan. Faktor kebudayaan memiliki pengaruh paling luas terhadap perilaku konsumen. Produsen harus memahami peran yang dimainkan kultur, sub-kultur dan kelas sosial pembeli.

2. Faktor Sosial. Faktor sosial juga dapat menentukan perilaku konsumen seperti kelompok kecil, keluarga, peran dan status sosial dari konsumen.

3. Faktor Pribadi. Perilaku konsumen dapat datang dari konsumen itu sendiri, karakteristik pribadi seperti umur, tahap daur-hidup konsumen, jabatan, ekonomi, gaya hidup, kepribadian dan konsep diri.

4. Faktor Psikologis. Kebutuhan yang bersifat psikologis dari konsumen seperti pengakuan masyarakat, harga diri, atau keutuhan untuk diterima oleh lingkungannya dapat mempengaruhi perilaku konsumen

Menurut Irawan [3], masyarakat kota di Indonesia khususnya Bandung adalah kelompok yang memiliki tingkat socializing yang kuat. Bahkan ungkapan orang Jawa yang menyatakan bahwa "berkumpul lebih penting daripada makan" 
sudah merupakan cerminan akan kekuatan pembentukan grup dan komunitas. Demikian pula, etnis Sunda, Minang, Bali, Batak dan lain-lain, juga memiliki kebiasaan yang kuat untuk hidup berkomunitas, gotong royong dan menjadi satu grup-grup. Adanya perkumpulan dalam bentuk dharma wanita, arisan, karang taruna adalah wujud perilaku nyata dari kehidupan berkomunitas masyarakat Indonesia.

Blijlevens, et al. [4] menjelaskan bahwa konsumen memandang setiap produk sebagai ringkasan atribut dengan kemampuan yang berbeda-beda dalam memberikan manfaat yang dicari dan memuaskan kebutuhan tersebut. Hal ini menunjukkan bahwa dalam suatu produk terdapat banyak atribut. Menurut konsumen dari semua atribut yang melekat pada produk tidak akan seluruhnya diperhatikan. Konsumen mempunyai sikap yang berbeda-beda dalam melihat atribut produk yang dianggap menonjol. Kosumen akan memberikan paling banyak perhatian pada atribut yang akan memberikan manfaat yang dicari atau dianggap paling penting.

Atribut produk atau mutu produk yang dalam hal ini adalah produk mobil ditentukan oleh beberapa indikator. Besar kecilnya peluang disukainya sebuah produk bergantung pada karakter psikologis masyarakatnya yang berhubungan dengan pengalaman nyata yang dialami langsung oleh pengguna. Faktor tampilan visual eksterior berperan penting dalam pembentukan citra, peningkataran kelas sosial dan kepuasan ego penggunanya. Inovasi desain secara visual juga membuat desain terdahulu ketinggalan zaman yang berpengaruh juga pada perubahan gaya hidup penggunanya.

Mobil juga bukan hanya sebagai objek fungsi, tetapi di beberapa aspek mobil dianggap sebagai objek fashion dan tren dimana sebuah tren datang dan pergi, beberapa tren begitu populer pada masanya lalu menghilang. Hal ini pun terlihat pada fenomena munculnya beberapa jenis kendaraan yang begitu populer di negara tertentu, kemudian diadaptasi oleh negara lain, kemudian di satu waktu tren tersebut menghilang.

Menurut Harrow dalam How to Design Car Like a Pro [5], ketika kita sadar bahwa kompleksitas dari mendesain sebuah kendaraan saat ini dengan segala aspek teknis, produksi, efisiensi, mengemas komponen, undang-undang dan regulasi kendaraan tanpa menyebutkan pihak-pihak yang terlibat dalam proses pembuatannya, terdapat ruang untuk kreativitas, inovasi dan keindahan, sebuah kata yang sering digunakan untuk mendefinisikan sebuah kendaraan. Desain kendaraan merupakan subjek yang kompleks, terlalu mudah jika kita menyebutnya sebagai proses styling atau perupaan. Karena keindahan dan kesan yang disampaikan pada sebuah kendaraan tidak datang secara spontan; seorang desainer kendaraan harus mampu memahami selera konsumen yang kemudian 
diterjemahkan kedalam bentuk tiga dimensi dengan keterlibatan aspek sejarah, emosi, serta budaya.

\subsection{Data Lapangan}

Industri otomotif di Indonesia mulai berkembang pada tahun 1970, Pemerintah Indonesia mengeluarkan beberapa kebijakan untuk mendukung industri otomotif di Indonesia seperti SK menteri perindustrian No.307/M/SK/8/76, SK menteri perindustrian No.231/M/SK/11/78 dan SK menteri perindustrian No.168/M/SK/9/79 tentang ketentuan keharusan mempergunakan komponen buatan dalam negeri dalam perakitan kendaraan bermotor komersil.
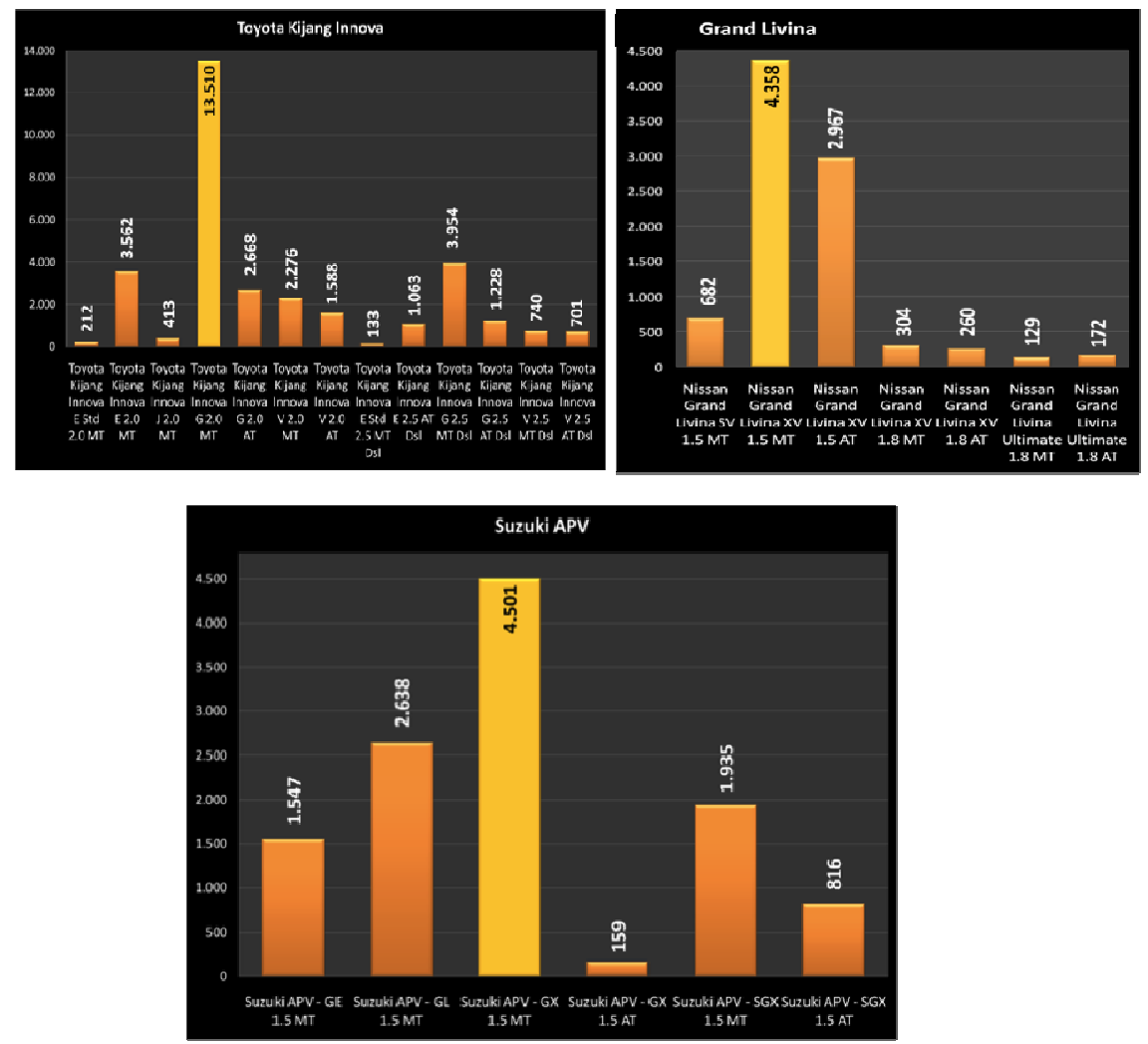

Gambar 1 Innova, Grand Livina, APV dan angka penjualan di Indonesia 2009 [6].

Dalam 2009, angka penjualan mobil di Indonesia berkisar antara 485.000 unit dan hingga kini pada tahun 2011 sudah mencapai 900.000 unit kendaraan yang 
diserap oleh pasar di Indonesia (Gambar 1). Dalam studi kasus ini, Kijang Innova, Grand Livina dan APV sebagai kendaraan medium MPV 7 seater yang memiliki angka penjualan 6 besar tertinggi di Indonesia. Namun pada grafik di atas, menunjukkan bahwa kendaraan yang terjual hanya ada satu varian yang memiliki tingkat penjualan tertinggi.

\section{a. Toyota Kijang Innova (Gambar 2)}

Kendaraan MPV yang sudah ada sejak tahun 1977 yang awalnya sebagai kendaraan kengangkut barang di Indonesia dan kemudian dikembangkan menjadi kendaraan pengangkut penumpang pada tahun 1986 hingga kini. Kijang Innova memiliki 4 varian yaitu E, J, G dan V dengan 2 tipe mesin yaitu bensin 2.0 liter dan diesel 2.5 liter yang dibagi menjadi 2 tipe transmisi; manual dan otomatis.

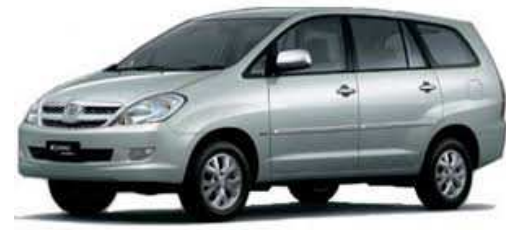

Gambar 2 Toyota Kijang Innova [7].

\section{b. Nissan Grand Livina (Gambar 3)}

Kendaraan MPV ini mulai ada sejak tahun 2007 yang merupakan pengembangan dari Nissan Livina. Walaupun masih tergolong baru, Grand Livina mampu menjadi salah satu MPV yang laris di Indonesia. Dengan 3 varian yaitu SV, XV, Ultimate dengan 2 kapasitas mesin 1.5 liter dan 1.8 liter manual dan otomatis.

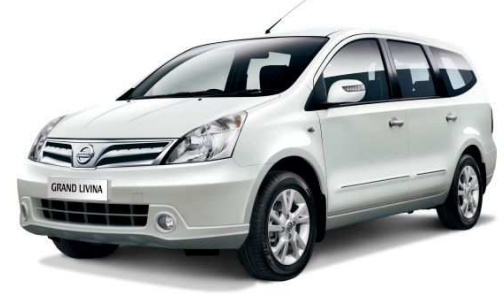

Gambar 3 Nissan Grand Livina [8].

c. Suzuki APV (Gambar 4)

Kendaraan MPV ini merupakan pengembangan dari suksesor Suzuki Futura yang saat ini sudah tidak diproduksi lagi oleh Suzuki.APV memiliki 4 varian GE, GL, GX, SGX dengan kapasitas mesin 1.5 liter dan transimisi manual. 


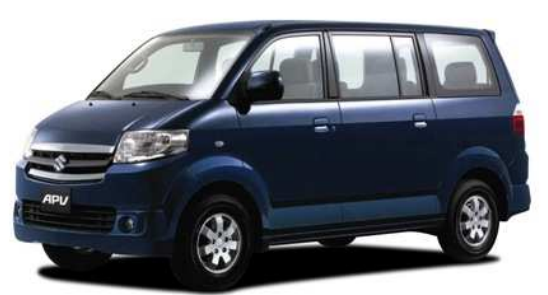

Gambar 4 Suzuki APV [9].

\subsection{Data Kuesioner}

Kuesioner sebarkan kepada pemilik kendaraan yang dijadikan sebagai objek penelitian yaitu Kijang Innova, Grand livina dan APV. Kuesioner terdiri dari 20 pertanyaan utama dan 14 pertanyaan essay untuk menjelaskan lebih rinci pengenai persepsi pengguna terhadap kendaraan yang dimilikinya. Kuesioner ini bertujuan untuk mengetahui aspek apa saja yang menjadi pertimbangan dalam membeli kendaraan dan mengetahui ekspektasi pengguna terhadap kendaraan yang dibelinya.

Metode pengolahan data yang dilakukan pada kuesioner yang sudah di kumpulkan adalah dengan menggunakan metode Likert-scale dimana metode ini biasa digunakan untuk mengetahui kecenderungan pada proses memilih dan menentukan sebuah keputusan seseorang. Metode ini memiliki besaran skala 15 untuk mengukur jawaban responden yang bersifat subjektif.

Metode ini kemudian dikembangkan untuk menentukan sebuah gap antara konsep kendaraan yang ditawarkan oleh produsen (prinsipal dan ATPM) dengan pengalaman yang dirasakan oleh penggunanya. Gap tersebut kemudian menghasilkan selisih antara angka expected value dengan angka perceived value yang dibagi dengan jumlah responden dari setiap merek kendaraan (14 responden).

Batasan konsep untuk diterima atau tidaknya konsep tersebut oleh responden adalah 0 sampai dengan 0,5 dan 0 sampai dengan -0,5.Sehingga grafik yang dihasilkan adalah:

\section{a. Grup Pertanyaan I:}

Dari Gambar 5 dan Tabel 1 dapat diketahui hirarki persepsi pengguna terhadap kendaraan yang dimilikinya. 


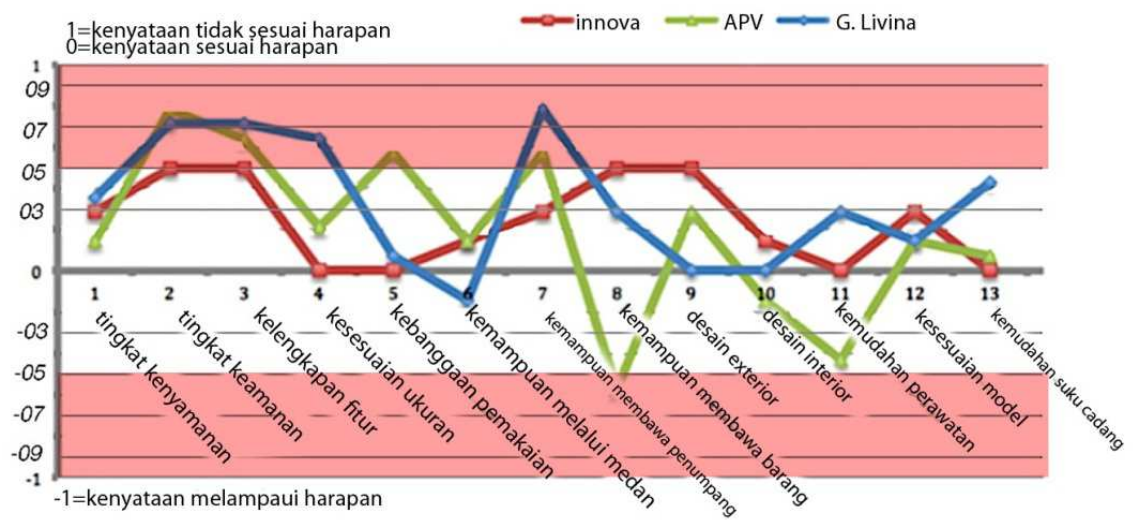

Gambar 5 Grafik Persepsi Pengguna Terhadap Desain Kendaraan MPV [10].

Tabel 1 Hirarki Persepsi Pengguna Terhadap Desain Kendaraan.

\begin{tabular}{lll}
\hline \multicolumn{1}{c}{ Kijang Innova G } & \multicolumn{1}{c}{ Grand Livina XV 1,5L } & \multicolumn{1}{c}{ APV GX } \\
\hline Kesesuaian ukuran & Desain Eksterior & Tingakt kenyamanan \\
$\begin{array}{l}\text { Kebanggaan dalam } \\
\text { berkendara }\end{array}$ & Desain Interior & Kemampuan melalui medan \\
Kemudahan Perawatan & Kemampuan membawa & Kesesuaian model \\
Kemudahan suku cadang & barang & \\
Tingkat keamanan & Kesesuaian Model & \\
$\begin{array}{l}\text { Fitur lengkap } \\
\text { Kemampuan melalui medan }\end{array}$ & & \\
Kemampuan membawa & & \\
penumpang & & \\
\hline
\end{tabular}

Dapat diketahui bahwa Kijang Innova dianggap sebagai kendaraan 7 penumpang yang memenuhi kebutuhan masyarakat di Kota Bandung, sistem keamanan yang cukup baik, memiliki fitur-fitur yang dibutuhkan oleh pengguna, kemampuan yang baik untuk melalui medan yang ada di Indonesia seperti kondisi banjir, Tanjakan serta jalanan yang rusak, kemudahan dalam merawat dan mendapatkan suku cadang serta brand Toyota yang dikenal oleh masyarakat Indonesia. Sehingga ketika konsumen membeli Innova maka yang dilihat sebenarnya adalah aspek-aspek teknisnya saja, aspek tampilan pada Innova dianggap sebagai sesuatu yang biasa karena konsumen memiliki visual experience mengenai desain Kijang generasi sebelumnya.

Nissan G. Livina sebagai kendaraan baru yang memiliki desain serta bentuk yang berbeda dari MPV pada Innova dan APV diminati masyarakat karena ukurannya yang lebih kecil serta desain eksterior - interiornya yang baik karena kesan sedannya yang ingin disampaikan oleh Nissan pada G. Livina. sehingga dapat disimpulkan bahwa ketika konsumen membeli G. Livina maka yang 
dilihat adalah impresi desain yang ditangkap oleh mata konsumen, interior maupun eksteriornya membuat G. Livina mampu menarik perhatian konsumen.

APV yang merupakan kendaraan yang memiliki dimensi paling besar namun memiliki jarak sumbu roda lebih sempit, hal ini berpengaruh pada handling dan stabilitas saat menikung. Di antara ketiga mobil yang dianalisa, hanya APV yang mengandalkan luas kabin serta kenyamanan penumpang karena ukurannya yang besar sehingga angka penjualan APV yang menempati urutan ke-5 dari 6 kendaraan MPV dengan penjualan tertinggi dianggap sebagai sebuah kebutuhan masyarakat akan kendaraan 7-9 penumpang yang mampu dijadikan sebagai kendaraan niaga bukan sebagai kendaraan keluarga dengan desain yang diminati dan berbagai fitur kemudahan bagi penggunanya.

\section{b. Grup Pertanyaan II:}

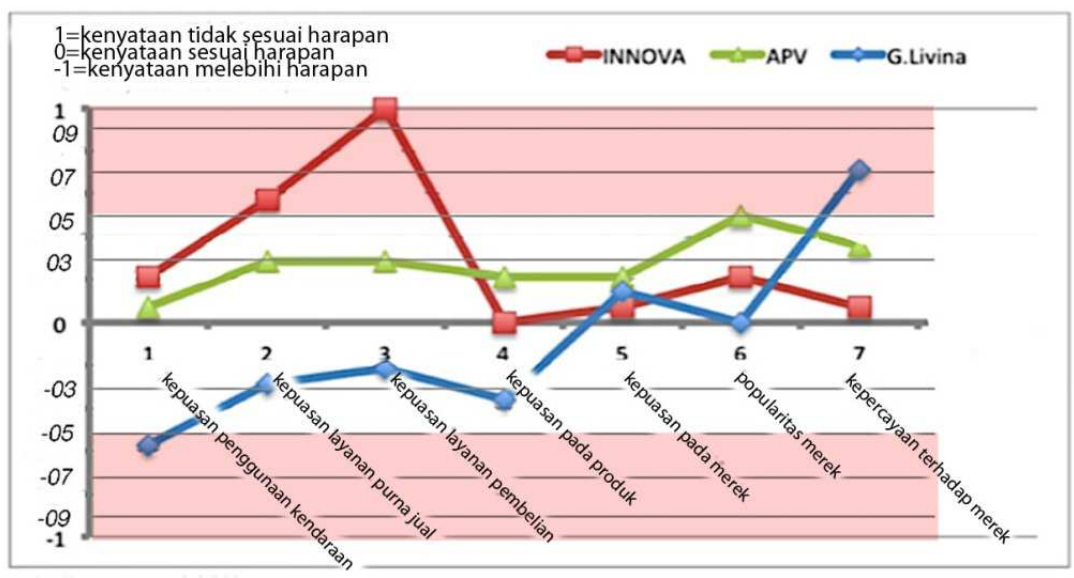

Gambar 6 Grafik Deskripsi Pengambilan Keputusan terhadap Pembelian Mobil [10].

Tabel 2 Hirarki Deskripsi Konsumen Terhadap Pengambilan Keputusan.

\begin{tabular}{lll}
\hline \multicolumn{1}{c}{ Kijang Innova G } & \multicolumn{1}{c}{ Grand Livina XV 1,5L } & \multicolumn{1}{c}{ APV GX } \\
\hline Kepuasan produk & Popularitas merek & $\begin{array}{l}\text { Kepuasan penggunaan } \\
\text { Kendaraan }\end{array}$ \\
Kepuasan penggunaan & Kepuasan layanan pembelian & $\begin{array}{l}\text { Kepuasan layanan purna jual } \\
\text { Tingkat kepercayaan merek }\end{array}$ \\
Kepuasan merek & & \\
\hline
\end{tabular}

Dari Gambar 6 dan Tabel 2, dapat diketahui bahwa ketika masyarakat memilih Innova adalah karena merek Toyota yang sudah dikenal luas dan sudah 
dipercaya oleh sebagian besar masyarakat di Indonesia. Produk-produk Toyota yang lainnya pun dikenal baik dari segi kualitasnya.

Ketika masyarakat memilih G. Livina, hal ini adalah karena desain MPV buatan Nissan memiliki desain yang baik dan diminati oleh masyarakat Indonesia yang sudah jenuh dengan desain MPV yang sebagian besar sama. Oleh karena itu impresi yang ditunjukkan oleh Nissan dalam G. Livina-nya mampu mempengaruhi minat konsumen.

Ketika masyarakat memilih APV, maka kemungkinannya adalah konsumen merupakan keluarga besar dan berjenis kelamin pria. Hal ini karena dari desain eksterior APV dapat dilihat bahwa dengan ground clearance yang tinggi, maka pengemudi wanita akan kesulitan ketika hendak masuk kedalam kabin. APV memiliki kabin yang luas dan jumlah penumpang yang lebih banyak dibandingkan dengan MPV lainnya, terutama pada tipe bawah. Sehingga konsumen banyak yang menggunakan MPV ini menjadi kendaraan niaga dan pengangkut barang.

\section{Data Videografi Perilaku Pengguna saat Berkendara}

Data videografi diperlukan untuk mengetahui berbagai aspek yang terjadi pada user dan penumpang lain (keluarga) selama mengendarai kendaraan MPV.

Durasi video direkam selama 30 menit perjalanan dengan keluarga menggunakan kendaraan MPV yang dijadikan objek analisis yaitu Kijang Innova, Grand Livina dan APV. Dalam video ini terdapat aktivitas-aktivitas yang memiliki kesamaan dengan video pada kendaraan lainnya yaitu: memasang seatbelt, menyetir, interaksi dengan penumpang, dan parkir. Sedangkan aktivitas lainnya hanya terjadi pada video kendaraan tertentu (lihat Gambar 7). Dalam ketiga sequence, terdapat kesamaan aksesoris interior yang digunakan oleh pengemudi, yaitu:

a. Neck rest pillow untuk menyangga leher pengemudi terpasang pada ketiga kendaraan yaitu Innova, APV dan G. Livina (lihat Gambar 8).

b. Aktivitas paling intens terjadi pada menit-menit awal dimana pengemudi harus mempersiapkan kendaraannya dan mengecek penumpang lain dan pada posisi berhenti/parkir, dimana pengemudi harus melakukan aktivitas yang sama dengan aktivitas sebelum mengemudi.

c. Pada beberapa sequence, terdapat aktivitas dimana pengemudi melihat jam tangan walaupun pada panel dashboard sudah disediakan jam digital (lihat Gambar 9). 


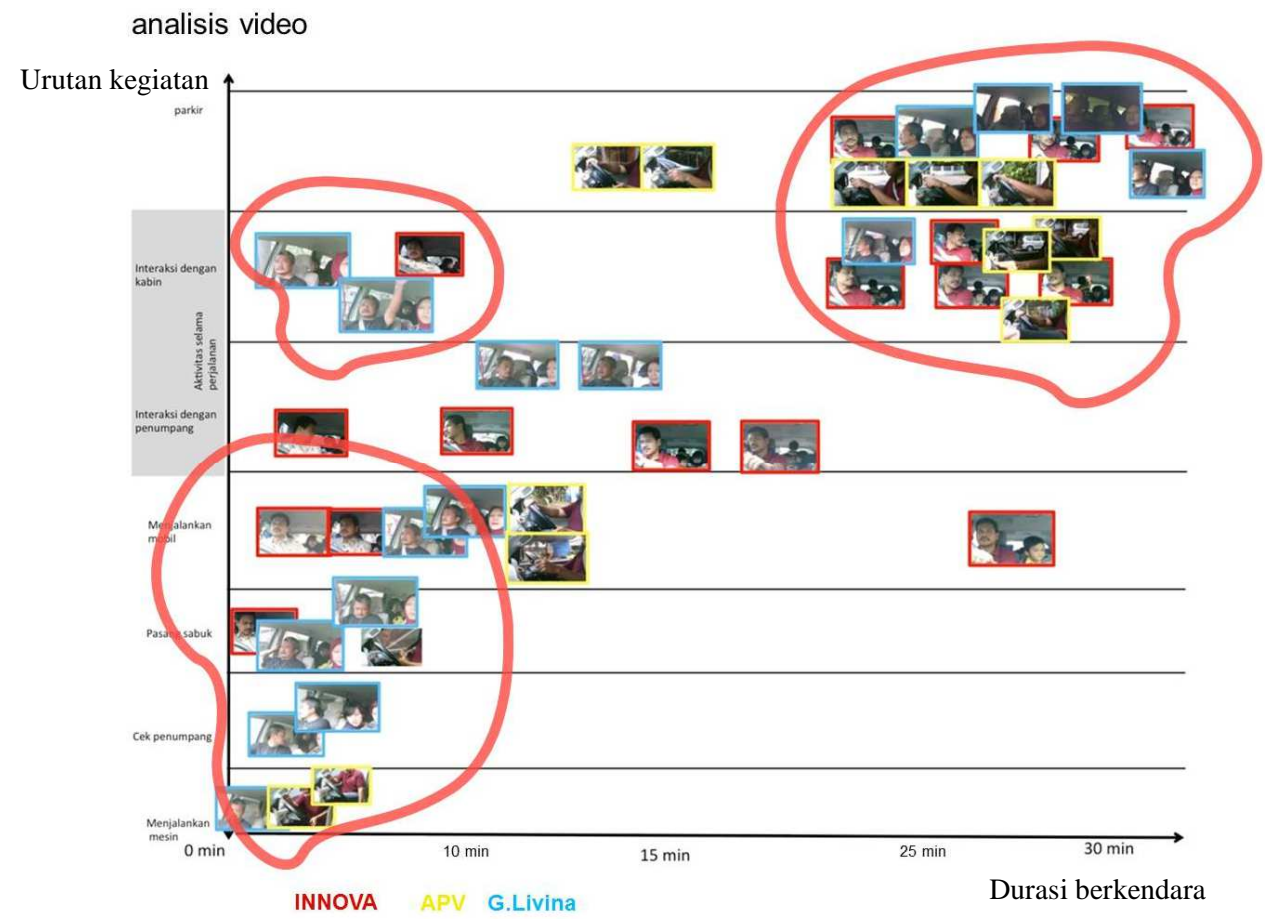

Gambar 7 Video analisis Interaksi Pengguna dengan fitur Kendaraan MPV.
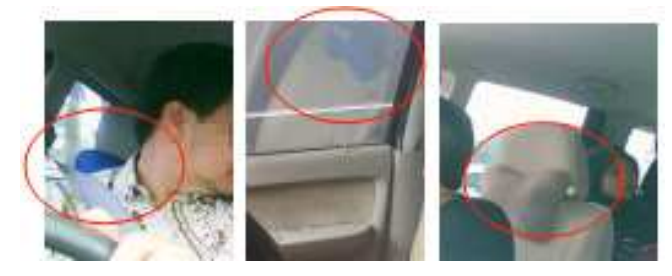

Gambar 8 Aksesoris neck rest pillow.

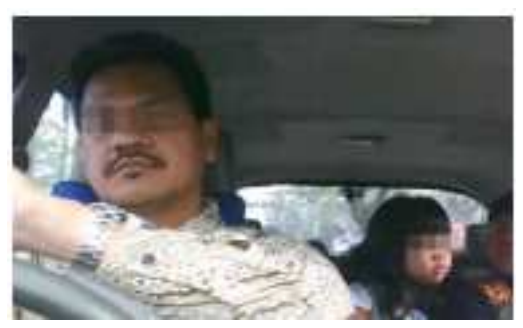

Gambar 9 Aktivitas melihat jam pengemudi Innova. 


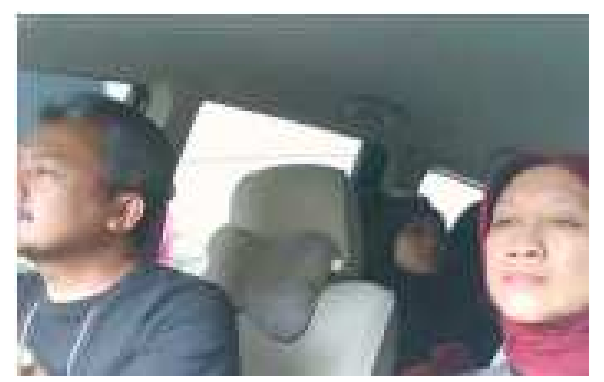

Gambar 10 Aktivitas memasang seatbelt.

d. Dalam sequence G. Livina, pengemudi memasang seatbelt setelah kendaraan berjalan, walaupun G. Livina dilengkapi dengan indikator seatbelt pada tachometer, namun hal ini tetap diabaikan oleh pengemudi (lihat Gambar 10).
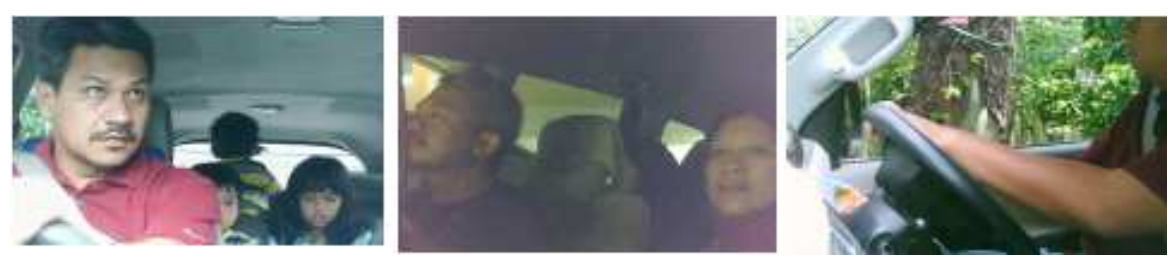

Gambar 11 Posisi pengemudi pada saat parker.

e. Posisi pengemudi lebih rendah dari MPV lainnya yang dianalisis, sehingga pada saat melakukan parkir, posisi duduk pengemudi berubah menjadi condong kedepan karena terhalang oleh bonnet (lihat Gambar 11).

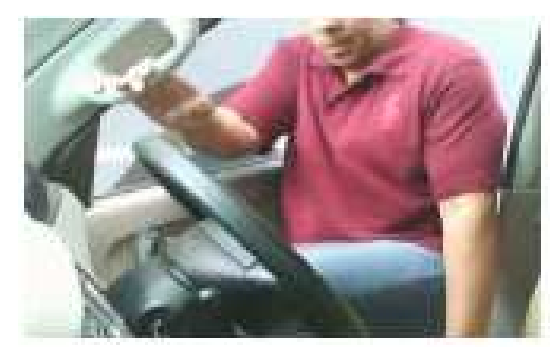

Gambar 12 Posisi pengemudi APV pada saat masuk kabin.

f. Dalam sequence APV, aktivitas keluar-masuk pengemudi selalu diawali dengan memegang handlebar pada pilar A, hal ini dikarenakan APV memiliki dimensi ketinggian yang lebih dari MPV lainnya (lihat Gambar 12). 
g. Posisi menyetir APV lebih kaku dan tegap karena posisi stir berada sejajar dengan dada pengemudi, posisi mengemudi ini mirip dengan posisi pada Suzuki Carry.

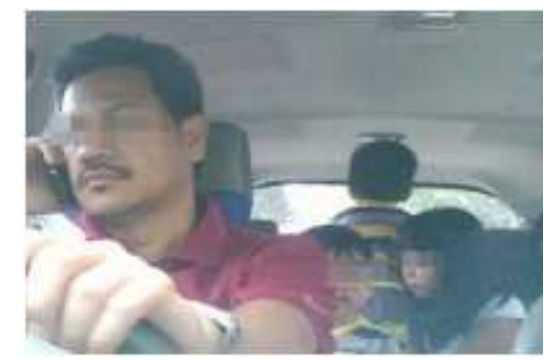

Gambar 13 Aktivitas menelepon pengemudi Innova.

h. Dalam sequence Innova, aktivitas pengemudi terekam pada saat melakukan panggilan telepon pada saat ditengah perjalanan pada menit ke-20 (lihat Gambar 13).

i. Posisi menyetir pada Innova lebih ideal, terlihat pada aktivitas parkir, posisi duduk pengemudi tidak berubah.

j. Aktivitas interaksi dengan penumpang jarang terjadi pada min. 10-20", aktivitas selain menyetir pun hanya sedikit seperti mengganti gear, tuas turning sign.

\section{$4 \quad$ Analisis}

Industri kendaraan di Indonesia merupakan industri pendukung dari industri besar yang sebagian besar berpusat di Jepang seperti Toyota, Suzuki, Nissan.Di Indonesia, berbagai macam merek industri kendaraan berada di bawah kendali beberapa perusahaan ATPM besar di Indonesia, seperti Astra dan Indomobil.

Astra merupakan ATPM besar yang tidak hanya memegang kendali Toyota di Indonesia, tetapi juga merek kendaraan lainnya seperti Isuzu, Daihatsu dan Honda.Suzuki di Indonesia berada di bawah Indomobil dan Nissan berada di bawah Nissan Motor Indonesia.

Toyota, Suzuki dan Nissan di Indonesia memiliki tim R\&D yang menjadi tim untuk merancang dan memproduksi komponen serta produk yang akan dipasarkan di Indonesia setiap periodenya seperti minor change, aksesoris, maupun major change untuk memenuhi kebutuhan penggunanya. Kemudian setiap perusahaan yang dipegang oleh ATPM memiliki tim R\&D yang menangani masalah developing sebuah produk yang akan dibuat dan dipasarkan 
di Indonesia seperti aksesoris maupun unit mobil itu sendiri dengan supervisi dari prinsipal.

Namun pada prakteknya, proses pengembangan desain kendaraan di Indonesia tidak menerapkan standar pengembangan desain kendaraan yang biasa diterapkan oleh Industri perakitan dan pengembangan kendaraan lain.

Terdapat beberapa faktor yang mempengaruhi sebuah desain kendaraan yang beredar di Indonesia:

1. Tim survey dari prinsipal yang selalu berganti dari setiap project yang dilakukan sehingga tim tidak menguasai kondisi lokasi dan masyarakat di Indonesia. Pada umumnya, proses desain dari prinsipal selalu mengacu pada kondisi ideal masyarakat di negaranya, yaitu Jepang.

2. Lokasi survey dilakukan di kota yang bukan menjadi kota dengan angka penjualan tertinggi seperti kota Jakarta dan Bandung. Dalam beberapa kasus sering terjadi kesalahan pemilihan lokasi survey seperti yang dilakukan oleh prinsipal Suzuki dimana lokasi survey dalam proyek pengembangan salah satu kendaraan memilih lokasi survey di Kalimantan.

3. Kurangnya komunikasi dan diskusi antara tim survey dari prinsipal dan marketing dari ATPM sehingga lokasi survey, target pasar dan keluaran produk menjadi tidak maksimal. Kondisi ideal adalah di mana negara prinsipal datang ke Indonesia untuk mendiskusikan masalah lokasi survey, keinginan \& kebutuhan pasar serta melakukan join project sehingga nilai local content pada kendaraan yang diproduksi dan dipasarkan di Indonesia ada keterlibatan dari pihak ATPM.

4. Tim marketing Indonesia menjadi dominan dalam menentukan sebuah desain dari tim R\&D. Hal ini terjadi hampir di setiap ATPM yang ada di Indonesia, tim $R \& D$ dan marketing berjalan masing-masing yang pada akhirnya kondisi saat ini adalah ATPM mengadopsi desain prinsipal dan dipasarkan di Indonesia tanpa melalui proses evaluasi desain yang sesuai dengan kebutuhan masyarakat Indonesia.

5. Fasilitas pendukung dalam proses perancangan dan pengembangan kendaraan yang disediakan prinsipal belum memenuhi standar sehingga produktivitas ATPM dalam mengembangkan sebuah produk tidak maksimal.

6. Salary beberapa pegawai ATPM termasuk marketing dan R\&D masih di bawah standar yang diberlakukan oleh prinsipal dan ATPM negara lain seperti India dan Thailand dan Jepang.

Pada hasil kuesioner, hasil perhitungan tertinggi ada pada Kijang Innova, kemudian Grand Livina dan APV. 
Dari hasil kuesioner dapat disimpulkan bahwa persepsi desain kendaraan bagi masyarakat adalah kendaraan yang memiliki fitur dan keamanan yang lengkap, mampu mengakomodasi semua kebutuhan penggunanya serta ukuran yang sesuai dengan harga yang dikeluarkan. Kendaraan tersebut pula harus memiliki tingkat kemudahan suku cadang dan layanan yang baik di lingkungan konsumen sehingga tingkat kepuasan konsumen terhadap produk meningkat dan pada akhirnya nilai jual kendaraan menjadi tinggi dan nilai kendaraan secara psikologis juga ikut meningkat (kebanggaan akan kepemilikan kendaraan tersebut).

Setelah tingkat kepercayaan konsumen terhadap merek sudah terpenuhi, maka konsumen akan selalu menganggap model kendaraan selanjutnya yang dikeluarkan merek tersebut (dalam kasus ini adalah Toyota) akan dianggap memiliki kualitas dan tingkat kepuasan produk yang sama. Hal ini yang terjadi pada Kijang Innova dimana Kijang generasi sebelumnya merupakan kendaraan niaga dan angkutan barang dan kemudian dikembangkan menjadi kendaraan penumpang hingga mendapat kepercayaan masyarakat sebagai kendaraan keluarga yang ideal saat itu.

Jika melihat dari parameter mengenai atribut produk kendaraan, terdapat poinpoin atribut dibawah adalah analisis berdasarkan hasil kuesioner:

\section{a. Performa, Kehandalan dan Ketahanan Performa pada ketiga kendaraan yang dianalisis terletak pada kapasitas mesin}

Innova unggul karena kapasitas mesin pada Innova adalah 2.0L pada mesin bensin dan 2.5L pada mesin diesel.Dengan dimensi body yang cukup besar, penggerak roda belakang dan kapasitas mesin sebesar itu cukup untuk melalui berbagai kondisi jalan di Indonesia seperti tanjakan, jalanan berbatu dan banjir. Berbeda dengan Innova, Grand Livina menawarkan dua jenis kapasitas mesin yaitu $1.5 \mathrm{~L}$ dan $1.8 \mathrm{~L}$ dengan penggerak roda depan. Hal ini menjadi kekurangan terutama pada tipe mesin $1.5 \mathrm{~L}$ mengalami kendala pada kondisi jalan menanjak dan kondisi banjir karena ground clearance lebih pendek dari ketiga kendaraan yang dianalisis. Pada Suzuki APV, kapasitas mesin adalah 1.5L dengan penggerak roda belakang dan ground clearance yang tinggi sehingga kondisi jalan yang menanjak tidak separah yang dialami oleh Grand Livina karena perbedaan penggerak roda. Selain itu pada kondisi jalan yang banjir, APV dan Innova dengan ground clearance yang tinggi ditambah mesin diesel pada Innova 2.5L mampu dilewati dengan mudah, berbeda dengan Grand Livina yang memiliki dimensi lebih rendah dari keduanya. 


\section{b. Fitur Kelengkapan}

Fitur kelengkapan pada Kijang Innova mampu diterima oleh masyarakat karena memiliki keunggulan-keunggulan seperti sunglass box holder,dual glovebox, kelengkapan safety equipment, audio control pada stir serta kelengkapan lainnya yang tidak dimiliki oleh kendaraan MPV lain. Masyarakat Indonesia masih memiliki keinginan untuk menonjolkan diri dari kelompoknya dengan menunjukkan apa yang digunakan atau apa yang di miliki. Sehingga kelengkapan fitur yang dimiliki dan harga kendaraan yang tinggi yang pada akhirnya pemiliki MPV ini menjadi lebih unggul dibanding dengan pemilik MPV merek lain yang memiliki fitur yang kurang lengkap.

\section{c. Kenyamanan}

Tingkat kenyamanan yang di tawarkan pada Suzuki APV menunjukkan angka yang lebih tinggi, hal ini disebabkan dimensi kabin pada APV yang besar dan jarak kaki dengan jok bagian depan lebih luas. Namun jika dilihat dari keseluruhan hasil penghitungan kuesioner menunjukkan angka penjualan tertinggi terdapat pada Kijang Innova. Hal ini menandakan bahwa tingkat kenyamanan pada kendaraan bagi masyarakat penggunanya tidak terlalu diutamakan, karena dengan adanya kelengkapan fitur dan penambahan aksesoris pada interior bahkan melapisi jok dengan material lain menjadi cara untuk meningkatkan kenyamanan masing-masing pemilik kendaraan sehingga faktor utama mereka membeli kendaraan. Pada Kijang Innova, kenyamanan yang ditawarkan adalah kelengkapan fitur yang dapat dinikmati oleh pengguna, pada tipe G, Kijang sudah dilengkapi dengan double blower air conditioner dan kelengkapan lainnya dengan kapasitas mesin yang paling tinggi yaitu $2.0 \mathrm{~L}$ dan 2.5L diesel dibanding dengan 2 mobil lainnya yang hanya $1.5 \mathrm{~L}$ dan $1.8 \mathrm{~L}$. sehingga Kijang Innova lebih kuat jika menghadapi kondisi jalanan di Indonesia.

\section{d. Kemudahan Perawatan}

Perawatan Nissan Grand Livina dibuat dengan konsep zero maintenance, di mana konsumen tidak perlu memeriksa kondisi kendaraan secara berkala seperti 3 bulan sekali mengecek kondisi kendaraan ke bengkel. Namun pada prakteknya, dukungan akan tersedianya tempat-tempat perawatan dan pusat service terutama pada daerah-daerah menjadi hal yang paling utama yang dipertimbangkan oleh konsumen dalam meemilih kendaraan. Untuk Suzuki dan Toyota, yang termasuk merek kendaraan yang populer terutama pada kendaraan MPV kelas menengah, lebih mudah dijumpai pusat perawatan dan service center di beberapa daerah mengingat bahwa pengguna APV sebagian besar dipakai sebagai kendaraan niaga. 


\section{e. Desain dan penampilan}

Jika melihat dari grafik kuesioner yang ada sub bab 3, desain yang paling diminati adalah desain dari Nissan Grand Livina, dikarenakan kondisi jalan di beberapa kota besar di Indonesia sudah semakin padat karena semakin banyaknya kendaraan pribadi terutama kendaraan MPV dengan desain yang pada umumnya memiliki dimensi yang besar dan tinggi sehingga semakin lama konsumen kendaraan MPV semakin jenuh. Desain Grand Livina memiliki ketinggian Roof yang rendah dibanding dengan MPV lainnya. Oleh karena itu minat konsumen akan kebaruan dari desain kendaraan 7 penumpang dan kapasitas bagasi yang luas semakin tinggi. Akan tetapi, angka penjualan tertinggi yang ada pada ketiga kendaraan yang dianalisis menunjukkan kelengkapan fitur dan pengaruh merek masih menjadi dominan. Hal ini dijelaskan pada poin $b$.

\section{f. Kualitas yang dirasakan Konsumen}

Dalam konteks ini kualitas kendaraan yang dirasakan adalah pada saat pengoperasian, berdasarkan analisa video, menunjukkan bahwa Kijang Innova mendapatkan angka tertinggi akan kepuasan konsumen terhadap produk Kijang Innova. Jika dikaitkan dengan hasil perhitungan akhir menunjukkan kepuasan terhadap Innova terletak pada kelengkapan fitur, tingkat keamanan kendaraan dan kapasitas penumpang. Sedangkan pada Nissan Grand Livina, konsumen mengalami kesulitan pada saat melakukan parkir. Selain itu, kabin belakang mengecil, sehingga penumpang dewasa akan merasa tidak nyaman ketika duduk di kabin belakang, sehingga desain eksterior dan interior pada kendaraan ini bukan menjadi faktor yang membuat konsumen merasa puas. Pada APV, kualitas yang dirasakan adalah karena APV merupakan platform yang mudah untuk di-custom karena dimensi kabin yang besar, sehingga APV banyak digunakan sebagai kendaraan niaga, ambulance, angkut penumpang dan blind van.

Analisis pada sequence video:

1. Konsumen pada ketiga kendaraan yang dianalisis merupakan jenis konsumen dengan perilaku membeli yang kompleks (complex buying behavior) dimana konsumen sendiri terlibat langsung dengan produk dan merek yang ditawarkan pada jenis MPV di Indonesia tergolong sangat banyak sehingga keputusan konsumen dalam membeli menjadi sangat penting karena sebagian besar kendaraan yang dibeli adalah kendaraan utama dan dikemudikan sendiri.

2. Jika dikaitkan dengan teori Kotler mengenai perilaku konsumen, masyarakat pengguna kendaraan yang dianalisis dipengaruhi oleh faktorfaktor seperti budaya, kelompok, pribadi dan psikologis. Hal ini tercermin 
dari perilaku membeli kendaraan dan menggunakannya sehari-hari. Hasil kuesioner menunjukkan nilai kebanggaan dalam berkendara, kelengkapan fitur dan kemampuan membawa penumpang menjadi kunci pada Kijang Innova menjadi kendaraan paling laris di antara ketiganya meskipun dari segi desain/tampilan interior dan eksterior secara teori mampu merepresentasikan status penggunanya, namun di Indonesia, yang menjadi faktor utama adalah kepopuleran kendaraan tersebut akibat kelengkapan fitur dan kapasitas penumpang serta kemudahan maintenance yang dapat merepresentasikan status penggunanya.

3. Dalam sequence video yang ditunjukkan, kelengkapan fitur pada tiap-tiap kendaraan tidak didukung dengan tingginya intensitas penggunaan. Hal ini terlihat dari pemasangan sabuk pengaman yang tidak menyeluruh pada setiap penumpang, penambahan aksesoris pihak ketiga pada interior seperti headrest pillow pada jok pengemudi menandakan bahwa kenyamanan jok bagi pengemudi masih tergolong kurang.

4. Penggunaan fitur pada dashboard pun masih tidak maksimal, kelengkapan seperti jam digital pada dashboard serta console box yang seharusnya digunakan, pada sequence ini pengemudi dan penumpang lain tidak memanfaatkannya (melihat jam tangan beberapa kali pada pengemudi Kijang Innova).

5. Kemudian indikator seatbelt pada dashboard diabaikan oleh pengemudi, khususnya pada pengemudi Grand Livina, beberapa kali keluar-masuk kendaraan dan menggunakan seatbelt setelah kendaraan melaju di jalan.

6. Proses parkir pada kendaraan menjadi faktor penentu perilaku mengemudi seseorang dengan desain kendaraan yang digunakan. Ketika parkir posisi duduk pengemudi Grand Livina berubah menjadi tegak dan berusaha melihat posisi bonnet agar mampu memperkirakan posisi kendaraan saat parkir, hal ini disebabkan ketinggian kursi dan jarak pandang pengemudi dengan panjang bonnet kurang sesuai dengan postur pengemudi.

\section{$5 \quad$ Kesimpulan}

Kondisi masyarakat ideal suatu negara dari produsen kendaraan seperti Jepang saat ini belum dapat dijadikan landasan untuk menentukan bahwa desain kendaraan yang dibuat akan mudah diterima oleh masyarakat di negara lain. Faktor-faktor lain pembentuk pola pikir masyarakat menjadikan kondisi masyarakat berbeda antar negara satu dengan negara lainnya, termasuk di Indonesia.

Persepsi masyarakat mengenai desain kendaraan bukan semata-mata dilihat dari perupaan dan penampilan dari kendaraannya saja, aspek lain bahwa masyarakat Indonesia masih peduli dengan kondisi-kondisi kebersamaan dan berkelompok serta memandang status sosial sebagai sesuatu yang dapat dicerminkan melalui 
kendaraan yang digunakan. Sehingga harga yang tinggi, kapasitas mesin yang besar, kelengkapan fitur ditambah dengan merek yang dikenal luas menjadi kombinasi pertimbangan bagi sebagian besar masyarakat urban di Kota Bandung dalam menentukan pilihan kendaraan.

Pola pikir masyarakat sebagai pengguna kendaraan MPV di Kota Bandung terhadap persepsi desain kendaraan dan mengambil keputusan dalam membeli dipengaruhi oleh kondisi-kondisi yang ada di sekitar mereka, seperti budaya, kelompok, pribadi serta psikologis seseorang sehingga kekuatan merek bukan menjadi satu-satunya faktor ketika suatu masyarakat sebagai pengguna memiliki aktivitas yang dapat didukung oleh fitur yang ada pada kendaraan yang mereka miliki seperti aspek kelengkapan fitur, kapasitas penumpang yang besar, kapasitas mesin sehingga aspek kenyamanan pada kendaraan saat ini yang sudah mampu diakomodasi oleh aksesoris buatan pihak ketiga sehingga aspek ini tidak lagi menjadi faktor utama dalam pengambilan keputusan oleh calon pengguna.

Cara pandang masyarakat sebagai pengguna pada kendaraan dengan life period yang lama seperti Kijang yang sudah mengalami 5 kali perubahan desain secara total, maka aspek-aspek desain yang ada pada kendaraan tersebut sudah tidak lagi menjadi pertimbangan utama, namun aspek-aspek lain yang menyertai kendaraan tersebut seperti banyaknya fitur yang ditawarkan (double din audio system/2 jenis pemutar musik, double blower AC hingga ke kabin belakang, dan perangkat-perangkat storage yang banyak seperti cup holder hingga ke kabin belakang) dibandingkan dengan generasi sebelumnya menjadi pertimbangan bagi calon pengguna.

Masyarakat urban di Indonesia sebagian besar masih memiliki perilaku yang berbeda dengan masyarakat dari negara asal prinsipal sebagai produsen. Nilainilai ideal masyarakat di Indonesia masih berpusat pada efisiensi dan keuntungan. Pertimbangan akan nilai kendaraan saat dijual kembali, dan fitur yang ditawarkan berbanding dengan harga yang harus dibayar menjadi pola pikir utama yang muncul ketika akan membeli kendaraan. Sehingga jika dilihat dari perilaku mereka saat mengemudi adalah masyarakat Indonesia masih mengabaikan aspek keselamatan, standar keselamatan yang ditawarkan oleh prinsipal seperti seatbelt pun masih sering diabaikan untuk digunakan, terutama pada penumpang tengah dan belakang. Selain itu, varian kendaraan yang digunakan cenderung tidak memiliki fitur airbag yang hanya ada pada varian tertinggi. Hal ini dapat disimpulkan bahwa masyarakat kita lebih memilih kendaraan dengan harga yang murah dan mampu mengangkut banyak penumpang dibandingkan dengan kelengkapan keselamatan yang ditawarkan. 


\section{Referensi}

[1] Pasaribu, M. 2006. Desain Mobil dan Gaya Hidup Masyarakat Kota di Indonesia: Membaca Selling Point melalui Desain Produk, JBPTITBPP, Bandung.

[2] Hermawan, A.A. 1995. Phillip Kotler: Manajemen Pemasaran, Jakarta, Salemba Empat.

[3] Irawan, H. 2008. 10 Karakter Unik Konsumen Indonesia, Jakarta: Publishing One.

[4] Blijlevens, J., Marielle, E.H. \& Creusen, J.P.L.S. 2009. How Consumers Perceive Product Appearance: The Identification of Three Product Appearance Attributes. Delft, Netherlands: Department of Product Innovation Management, Delft University of Technology.

[5] Lewin, T. \& Ryann, B. 2010. How to Design Car like a Pro, Mineapolis, USA: Motor Book.

[6] Gaikindo. 2009. Indonesian Domestic Automarket, www.Gaikindo.or.id/ download/statistic/

[7] Brosur Toyota Kijang Innova. 2010. PT. Toyota AstraMotor.

[8] Brosur Nissan Grand Livina. 2010. PT. Nissan Motor Indonesia.

[9] Brosur Suzuki APV. 2010. PT. Indomobil Suzuki Indonesia.

[10] Riyadi, S. 2011. Kajian Hubungan antara Desain Kendaraan MPV dan Penggunanya di Kota Bandung, Bandung: FSRD ITB. 